探掘場にも接續し，その上鐵隔も麻價に手に大るのである。

ヂュルースにとつて他の阻害要素は，南方にその競争相手が存する事である。以上 の如く見るとスペリオル湖頭のヂュルースを鐵及び鋼鐵工業の用地として選んだ事は 位置不適合の顯著なる一例といいよう。 矢島仁吉

\title{
有史前の景觀と聚落 [R．Gradmann]
}

Vorgeschichtliche Landwirtschaft und Besiedlung

Geogr. Zeist. 42 Jahr. (1936), Heft 9. 10., 378-386

磦業經濟學の 2 人の代表者, E. Klapp とA. Stählin が Thüringen の草地を 9 群落に區分せんとする仕事をやつたが，其の買摰さと精確さとは植物地理學者の注 目すべきるのである。此の磔究は嘗て䈉者が提唱した, Theorie der Vorgeschichtliche Besiedlung に全く豫期しなかつた關係があるのを見出した。筆者は此の勞作 の結果を利用して有串前の聚落說に一步を進めた。以下に記載する四つの爱點は, 次 の地域に全く適用される。中央ヨーロッパの內海地域に限られる。郎ちアルプス諸國, 南及び中央ドイッ，ベーメン及びメーレン，北東ドイッ低地，南スカンヂナビヤ，文 びイギリス楛島に適用されるが，エルべ河から西方の北西ドイッには全く適用されな い。

(1) 有央前聚落の不均等な分配。新石器時代の中葉から中世の初期まで, 聚落地域 の形態は同樣な將棋型で多少に拘らず人口调密なよく耕作された Kulturlandschaft は原始林地域と交互に存在する。この形態は植物地理學的な矿究を契機として原始林 の開拓に關する中世紀報告の蒐集や地名の㸴究によつて廣汎に實證せられた。

（2）古い聚落景觀と新しい聚落景觀との地理學的對比。それは今日に至る迄，只單 に森林數や森林の樍成に表現されてるるが，それのみならず更に一層强く，居住型や 耕地形式, 農業自治體規約に或は又之の國の相續慣㕷, 人口密度, 蓙業の分配, 都市 の形成，國民生活及び國民性の中に表現されてるる。

（3）草原性ヒース現象。有史前の聚落は其の擴りがあの自然のま〉なる群落の一つ 草原性ヒース Steppenheide と廣沉に一致すると云ふ事實である。Steppenheide を同じ樣に有史前聚落は乾燥した氣候か石灰に富む土壤か或は久兩方によつて目立つ てるる景觀に依存してるる（南ドイツは此の關係は降雨量 $700 \mathrm{~mm}$ 以下の地方に何處 
にでも見られる。700-1100mm の地方では只石灰質地域にのみ, $1100 \mathrm{~mm}$ 以上の地 方では岩石の相遥を間はず何處にも見られない)。從來，人間は先づ第一に最も暖かな 最も溫和な最も豐饁な土地を選ぶと云ふ說が自明の事とされて居る。文近くは Nietch 更び Tüxen によつて主張された Eichenwaldtheorie 椾の森說がある。しかし，溫 暖氣候或は又旅の森によつても特色付けられてるない大きな聚落の古い地域，例へば Schwäbiṣhe Albがある。これに反して最も顯堵な橉の森のある地域例へばSpessart では聚落の形成は崌かつた。

（4） Steppenheide 現象の解釋。既に數年前認められてるる植物地理學上の意見か ら出發して屚々論義されてるる假定に到達した。郎ち, 有史前の聚落は Steppenheide の植物と同じ理由から乾燥した石灰に富んだ地域に移つて行つたと。つまり此の地域 の氣候は一般に稍溫氣少くまばらな植生を持つてみる。一方，比較的溫潤な隣接地域

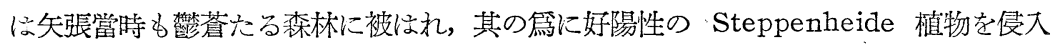
せしめない。又辪作をする移住者達をも進入せしめなかつた。他方では, 土壤の乾懆 と石灰に富むことは此の地域への森林の進出を困難ならしめ, Steppe の形成を良好 ならしめた。以上の解釋は現今の著しい森林泩氣候が早くも後期石器封代の終り頃, 恐らくは漸く青銅器時代の終りには一般的に擴つてるたことを前提とする。

以上の樣な見解に就いては其の支點も相當な數が制明してるる。吾人の知識の現狀 を以つてしては筆者は以上は成程可能な證明だと考へてるるが將來新事實が制明すれ ば本質的な補充をするつもりである。佮次に今少しく Steppenheide が如何にして 耕作地とされるかに就いて詳述する。

桀出した農業实家であり古代ゲルマンの專間家たる Cäsar と Tecitusによると古 代ゲルマン農業の耕地組織は所謂 Wilde Feldgraswirtschaft 原始的耕地草生經濟 であつた。それは唒百年前には現在より甚だ廣汎に拱つてるたが，現今でも個々の地 片唒ほ行はれてるる。それは，Ausfeld 又は Aussenfeld と呼ばれるもので遠隔 過ぎるとか交通困難のために全然施肥され妨必極く稀れにしか施肥されない耕地 である。此處では 1 度或は精々 2 年度代りに豰物が作られる。其後は不定期間, 霫 3 20 年又はそれ以上，草地 Dreisch 又は Dresche として再び“地力を集める”まで 放置される。やがて掘返され再び 1 司か 2 局の收穫をする。ドイッの耕地組織 Feldgrasswirtschaft, Dreifeldwirtschaft, Fruchtwechselwirtschaft 等は云ふまでも 
なく收檴による消耗郎ち植物盖分の消耗を出來るだけ好都合な形式, 主として厩肥を 施して消耗を補はんとするるのである. 原始的な Feldgrasswirtschaft では植物苓 分の補充が如何にして行はれるかが今日迄謎とされてるた。草地形式の Dreish 耕地 は年に僅か 1 度だけ收穫し得る痊瘦草地 Magerwiese である。これは Bromuserectus や無數の窒素には乏しいが石灰に富んだ土瓖を好む植物を持つた Trespenwiese であ る。だから著しく養分に泛しい土壤と云ふ印象を受けるが，芝草が掘り返されるや否 や此の土地の上に普通の窒素を好む耕地雜草と並んで溨培しにくい種々の穀物が無造 作に笅茂する。

この謎は前記の兩研究者 Klapp と Stählin とによつて解かれた。即ち Trespenwiesen の土塤, 多くの場合全然㾑瘦ではない又 “土壤學的に見ても農耕上から見て

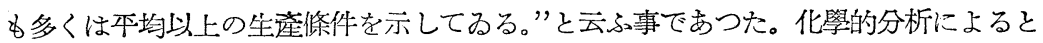
あらゆる種類の植物荃分が夥しく確登されてるる。しかし實驗が敋へる如く夫等の養 分は吸收され得ない形態で存在してるる。兩研究者は明快な方法でそれを乾燥，高度 の石灰含有及び微生物の活動の減少によるものとした。

鋤によつて芝草が掘り返され，土壤が軟くされるや否や酸素は豐かに流大し，活潑 な物質の置換が始まる。この物質は吸收の容易な形態とされ，以前には外見上瘦瘦で あつた土壤が忽にして水を多量に要しない植物の中, 最も栽培の困難なるのを生長せ しめ得るのである。

此の獨特の關係から Trespenwiese は一種の養分保藏作用を示すことが推定される。 常に無數に存在する营科植物の根瘤によつて土壤は空素化合物に富んでるる。其他の 植物盖分は土中に遺殘する植物殘湍の分解によつて又其他の方法によつて自由に生成 される。しかし夫等の中瘏瘦草地植物によつて消費されるのは單に一部分に過ぎない。 それで，年經る中に，繰り返し何可かの收穫を產み出し得るに充分なだけの荃分が集 積される。かくして初めて Liebig の諸見解以來, 殆ど考へ得べからざる事とされて るた無肥料の穀作形式（詳細は Stebutis: Bodenkunde 1930 年參照, 南ロシヤの Tschernojom-steppen 及び近東地方にも普通である。前者では穀物の每年の變更と 休閑による二围制をとるが氣候に惠まれないドイッでは何年もの土地の休養を必要と する）が如何にして一般に可能であるかを理解することが出來る。

以上の如くTrespenwiese はゲルマン古代の耕地組織に對して本質的意義を有して 
みる。Trespenwiese の地域は精確に Steppenheide と同じく乾燥した沃土に乏しい 石灰に富しだ土壤を有し, 比較的雨量の少い場所に限られてるる。Trespenwiese の主 要地域の一つたるUnstrut Becken は Drude の所謂“"pontische Genossenschaften” 黑海群の主要地域に一致する。Steppenheide 地域外には Trespenwiese はなく, こ の古代耕地組織なしには何の穀作もなければ古代移任民の生存の如何なる可能性もな い。故に間接的とは云へ聚落は Steppenheide一Landschaften に結びつけられなけ ればならない。かくして Steppenheide 現象に對する貝に新しい一つの解釋が發見さ れたと云つてい〉と思はれる。

坮以上のことから直ちに決定的な結論に入るのは早過ぎる。幾多の問題が碊つてる る。今日及び往時の原始的な Feldgrasswirtschaft の分布に關する調查が不充分であ るし，ドイッ以外の土地の調查が䇣急である。次にライン河流沿岸の古ゲルマン民族 の一 Ubier に就いては極めて集約的な畦掘りに似た土地改泉の仕方が報告され,ゴー ル人に就いては泥灰石施肥のことが報告されてるる。より困難なのは下ザクセンの特 殊地位である。北西ドイッには Steppenheide がないにも拘らず古い聚落がある。 こ〉には前記の如き古代ゲルマンの特殊農業組織があてはまらぬことになる。何とな れば，斯如き濕潤な石灰に乏しい地域では肥料をやら如耕地をDreisch として置け ば土壤の酸敗と泥灰化が起る。これは他の場所では, 石灰によつて防がれるのであるが。 地監類はその上に極めて溶け易くなり下層土に導かれ土壤は頚弱になり Borstengras やHeide が萝延し，遂に全體が荒野になつて了ふ。芝地切りと野火とによつて辛じ て穀作の䉆めに利用し得るに至る。云ふまですなく燃燒のために泥炭化したる植物殘 涬は再びその無機成分に分解され，その無機成分が新たに植物養分として役立つこと が出來るのだが，その際最も價值に富んだ成分が失はれる。火田制が以上の事にも拘 らず古い時代に支配的であつたか否か，又は下ザクセンでは特別に早く施肥が初めら れたかであるが詳細な調查を必要とする。

筆者は氣候と古代ゲルマンの移動の時代とを論じた後に次の如く氏族移動の過程を 一先づ結論してるる。新石器時代の中葉及び青銅時代に人間の少なかつた中央ヨーロ ッパ內地へ四方八方から移住が行はれた。それは恐らく彼等が Pflugkultur そそれ に結合してるる役畜の新な獲得によつて直接的な人間の食料に乏しい土地を一般に耕 作し得る狀態になつた爲でつた。森林の比較的柾らな所，大り込み易い所，比較的豐 
富な野獸生椿地，良好な牧場地，開墾の容易な所が彼等を誘つた。郎ちこの地域こそ， Steppenheide 地域である。彼等は此所で粗放的な本質的には無施肥農業によつて生 活し，世紀のうつるに從つて農業のこの型式が土地の性質によつて可能な範圍げけ拱 つて行つた。 伊 藤 隆 吉 